\title{
BOSSA NOVA: THE REINVENTION AND REINVIGORATION OF SAMBA IN THE 1950s
}

\author{
Martinus Helmiawan
}

\begin{abstract}
In a society where music becomes the core of its people's life, many discourses emerge and root in music. In Brazil, for instance, samba as the national music represents the chronicle of the Brazilians, which starts from the slavery in eighteenth century. However, at the start of the era of Brazil's modernism in 1950s, samba was deemed stagnant. It was unable to cope with the fast developments of Brazil's politics, societies, and cultures. This essay observes the history of samba, investigates the reasons why samba becomes stagnant and reviews the efforts made to revitalize it through the invention of Bossa Nova. In the process of redefining samba, American jazz plays an important role as the agent which brings modernity and revolution to the original samba. The ideology of the Brazilian urban middle class is also important, as well as Brazilian 1950s musicians' efforts such as Antonio Carlos Jobim, Joao Gilberto, or Vinicius de Moraes. This paper aims to analyze Bossa Nova's contributions in revitalizing and redefining samba, with its jazz influence which could be traced from the ideology of the Brazilian urban middle class. The paper also highlights the contradiction between foreign influences and traditional heritages in the music.
\end{abstract}

\section{Keywords}

Bossa Nova, samba, jazz, Brazil, popular music, modernism, Brazilian urban middle class, foreign influences, traditional heritages.

\section{INTRODUCTION}

The main objective of this essay is to give detailed explanations and analyses on how samba as a traditional music went through a major change in the late 1950s, in which it was transformed, reinvented, and reinvigorated into a new, more modern music, leaving its stagnant image behind. In countries around the world, there are many cases of peoples or societies starting to neglect their traditional heritages, such as traditional dances and music. They prefer more modern and trending music over traditional ones, which they consider boring, less prestigious, and stagnant. ${ }^{1}$ It is

\footnotetext{
${ }^{1}$ In Indonesia, for example, Korean wave dominates the national music scene, where many Korean boybands and girlbands receive huge portions of airtimes per day, in addition to sporadic founding of many locale boybands and girlbands. Traditional music (such as keroncong and many other regional
} 
interesting how samba could become a stagnant music, despite the fact that samba has been the 'national music' of Brazil, since the dictatorship era of President Getulio Vargas in the 1930s. The stagnancy of samba gave an opportunity for many musical influences to develop and flourish in Brazil, especially foreign musical styles. One particular style that successfully entered the Brazilian music scene was American jazz. The style's successful development in Brazil was in line with the new policy of President Juscelino Kubitschek, the new leader of the post-dictatorship era, which opened trans-national relationship in the 1950s with the United States, the home soil of jazz. Even though jazz was literally everywhere in Brazil at that time, Brazilians were never expecting something too foreign, and that was the very reason of the development of the new styled-jazzy samba, Bossa Nova by the middle-class Brazilians. The style not only successfully resurrected samba but also promoted the music to the international music scene. ${ }^{2}$ This shows how a dying traditional music could still be reinvigorated and redefined, leaving its outdated and boring image into something fresh, modern, and sophisticated.

Samba was born in Bahia, located in the northeastern region of Brazil. The samba rhythm had its root from Candomble, which is an ancient religion from native African tradition. The influence was brought by African slaves imported by the Portuguese colonials to Brazil in the 17th century. The religion is well-known for its percussions plays used in most of its religious ceremonies. The percussions beats and style were then evolved into a primitive form of samba. The beats would later be called as batucada. Then, it was spread throughout Brazil and eventually reached Rio de Janeiro, where native music and dances from European origin such as polka, maxixe and luntu were famous. Those musical styles had a great contribution in developing batucada into samba. During the period of President Vargas started in 1930, samba acquired the privilege as national music. However, it was in the 1950s of President Kubitschek when people started to think of samba as stagnant, boring, and even music of the lower class. As a result, many people believed it was the right time to reinvent and redefined the existing samba. Musicians such as Joao Gilberto, Antonio Carlos “Tom" Jobim, Carlos Lyra, and Roberto Menescal were the creative force in Brazilian fifties music (Thompson, 1998). They played samba, the fast paced and high tempo batucada, in a more relaxing and smooth way. Even the harmonies, improvisations, and chromatics features resembled those of American jazz and classical music. At that time, no one had thought that samba could be played in a jazzier and relaxed way, so the genre quickly became popular throughout the land. One more contributing element from Bossa Nova that is quite important for its success is the

music), on the other hand, are not popular and receive less to no airtime at all per day.

2 The music not only got promoted and exported to other countries, such as America and European countries, but also invited foreign musicians, such as Stan Getz, Charlie Byrd and Miles Davis, to come to Brazil in order to play and learn Bossa Nova (Moreno, 1982, p.136). 
lyrics. Vinicius de Moraes wrote almost all Bossa Nova all-time classics lyrics, including Garota de Ipanema. He was a playwright, poet, and essayist. However, he developed such strong interest in the newly born music genre. With Jobim's smart composition and arrangement, Gilberto's smooth and whispering voice, and captivating lyrics by de Moraes, it was inevitable that Bossa Nova reached its peak just in short space of time.

At the start of the research, I will gather as many data, evidences, and recollections as possible regarding the history and development of samba. The information will be used to identify the reasons and possible causes of the stagnancy of samba. This is the central problem for this essay, how traditional music could become stagnant. After that, I will look into efforts and actions taken by middle-class Brazilian to transform samba into something more modern and sophisticated, which is Bossa Nova. This part will focus on two aspects. First, I will see the reason behind the actions of middle-class Brazilians. Second, the analysis will be on the actions, from musical transformations to international promotion of Bossa Nova. Lastly, I will analyze the successful reinvigoration of samba through Bossa Nova and try to identify what lessons we, as Indonesians, could learn in order to reinvigorate our traditional music.

\section{PREVIOUS RESEARCH}

Despite the fact that most of them are published at least more than a decade ago, there are actually quite a number of expansive articles analyzing the phenomenon of Bossa Nova, from its emergence to influence on many things, such as political movement. Suzel Ana Reily (1996) compiles a good perspective on how and why Bossa Nova was invented by middle-class Brazilians, and the contributions of figures such as Antonio Carlos Jobim and Joao Gilberto to the development of Bossa Nova in the late 1950s. While she accurately points out the politicization of Bossa Nova, which in turn creates Musica Popular Brasileira (MPB), no attempt is made to explain relationship between samba and Bossa Nova. Detailed and descriptive explanations on Bossa Nova are also reviewed by Gerard Behague (1973), specifically in a more technical method. His explanations go as far as tropicalismo ${ }^{3}$, a style that emerged not long after the Bossa Nova movement had ended in the early 1960s. Still, the connection between samba and Bossa Nova is only explained as far as differences and changes from one style to another, with no further discussion on Bossa Nova's role in redefining samba.

With a quite recent date of publication, Bryan McCann's Blues and samba: another side of bossa nova history (2007) not only pleases, or shocks, most Bossa Nova enthusiasts and experts but also provides a very interesting and fresh ideological

\footnotetext{
${ }^{3}$ Tropicalismo is another product of popular music from Brazil which is characterized by its loose reference to rock. It continued the legacy of Bossa Nova in the post-1950s era of Brazil, which saw censorship and banning to any creative thought and opinion.
} 
perspective on Bossa Nova. As the journal's title implies, McCann argues that Bossa Nova should be considered and, in fact, is related to blues. While it has always been considered as the root of jazz, blues is never related to Bossa Nova. This is the central argument of McCann, that Bossa Nova also takes its root in blues, just like jazz. McCann then explains why Bossa Nova should be related to blues by providing technical analysis and also a bit of history about blues' influence in Rio de Janeiro. However, as expected, there is no discussion about samba's relationship to Bossa Nova, as the article mainly talks about blues. Another article that gives extensive knowledge about samba and Bossa Nova is the one from Albrecht Moreno (1982). He reviews many aspects about samba and Bossa Nova, from the historical origin of samba to the emergence of Bossa Nova movement. His study discusses even deeper the ideology of the middle-class Brazilians and further until the politicization of Bossa Nova and the era of tropicalismo. In short, Moreno's essay covers almost all important aspects of samba and Bossa Nova. However, the essay does not provide adequate coverage on the role that Bossa Nova played in order to revitalize samba as a stagnant traditional music.

\section{THEORY AND METHOD}

There are some theories that will be utilized in order to analyze the role that Bossa Nova plays in revitalizing and redefining samba. Most of them are theories of popular and global culture. An analysis from Magaldi (1999) states that there is always a conflict between the 'nationalist' and the 'pro-foreigner' in the Brazilian society and that conflict is clearly shown in the development of popular culture. The conflict which Magaldi suggests is usually about the foreign influences versus the traditional norms and values in a new product of culture, such as songs and music. In this case, Bossa Nova will be analyzed as a product of culture that has a foreign influence in its universality of jazz, especially American jazz, but at the same time retains the traditional samba beats. Other theory comes from Carney, who has done a detailed research on American jazz. Carney (2003) believes that American jazz had played an important role in the reorientation of African-Americans to the urban life in the 1920s America. This shows how jazz has an attribute of being a media of reorientation and redevelopment. In this essay, I will look into how jazz could reinvigorate samba in a similar way from how jazz helped the African-Americans' acclimatization to the urban life in 1920s.

The process of integrating foreign cultural influence into traditional one is not unanimously accepted by the whole Brazilian society, as stated above. Nationalists are always afraid of 'cultural cannibalism', a process of reintegrating one culture to another, while the pro-foreigners defend that foreign influences are important in delivering Brazil from cultural isolation (Magaldi, 1999, p. 310). In Brazilian popular music study, they are debates between Bossa Nova or jazz, and tropicalismo or rock. Leaving the debates aside, I believe that Bossa Nova is not in any way intended for assimilation between jazz 
and samba. Although I do not deny the existence of jazz influence in Bossa Nova, Bossa Nova is not a simple collaboration between jazz and samba. Bossa Nova is samba. It represents and redefines the traditional Brazilian samba beats. No other description fits Bossa Nova, as it is either invalid or not appropriate in accordance to the original spirit of Bossa Nova. ${ }^{4}$

The whole process of analyzing the main issue of this essay will be started by doing historical analysis from the era of samba until the end of Bossa Nova. There are many important events that occur in the history of Brazilian popular music, and I will try to find those events' relations and meanings to the development of samba and Bossa Nova. This part also includes the analysis of ideology brought by the middle-class Brazilian, who at that time had a significant impact in creating the new atmosphere of Brazilian popular music scene. After historical review, analyses will also be conducted on real product of samba and Bossa Nova, the songs themselves. The songs have many important elements such as lyrics, themes, and instruments. Because I will focus my research based on cultural studies, there will be only a few discussions regarding the technical and musical analyses from the corpus. Regardless, those will still be included in this research.

\section{Samba: From Candomble to National Music}

The most fundamental concept in Brazilian culture is that music plays an extremely significant role in shaping and forming its society, cultural life, and history. As Moreno suggests, "In Brazil, perhaps more than in any other Latin American nation, popular music has traditionally been a potent cultural force" (1982, p.129). There is no denying that popular music indeed has proved to be the main cultural motor in Brazilian society. However, as popular music is considered as crucial, Brazilian traditional heritage is often forgotten and taken as a mere fact. Frankly, samba as Brazilian traditional music is as equally important as the popular music in driving Brazilians' cultural force and lifestyle. It all began in the $17^{\text {th }}$ century of colonial era in Brazil, when the Portuguese imported slaves from Africa. At that time, sugar plantations could be easily spotted because Brazil's main commodity was sugar. With so many fields to work for, slaves were the answer to put the job done.

However, there were some differences between slaves in Brazil and in other countries. For one thing, African slaves in Brazil were allowed to keep their culture alive ("Samba: Origins of Samba", par.2). This included playing their traditional music.

\footnotetext{
${ }^{4}$ This is simply to make the border clearer between samba and jazz in Bossa Nova. While it is true that there are forms of Bossa Nova which put the emphasis in jazz, especially the newer forms such as NuBossa or the ever existing smooth jazz, the original Bossa Nova has never been intended to be merged and overlapped with jazz, thus the definition of Bossa Nova that I construct.
} 
However, Candomble, their native religion, were banned by the Portuguese colonialists because their objective was also to spread the Catholicism. The slaves worshipped the gods and goddesses in Candomble while at the same time they deceptively prayed to the Catholic saints, but the traditional percussions style used in the religion's ceremonies was still intact. The percussions style, or familiarly called Batucada is a drum-playing musical genre with high tempo and fast paced usually played in an ensemble (Starr, 2007). It survived in Brazil even after the slavery had been abolished in 1888. Batucada commonly followed the circle dance that was native to African culture, and that was the origin of the word samba. This style of samba was considered as samba raizes (samba root), and the circle dance was also known as samba de roda (samba circle), with both are still played even until today. After the abolishment of slavery in 1888, many of the slaves moved to Rio de Janeiro, where the Europeans and white cultures were dominant. It was a city where native European music and dances such as polka, maxixe and luntu were famous. Then, it was the people from Bahia and Rio who mixed batucada with their music, creating new and different forms of the modern samba in the process (Samba: origins of samba", n.d).

Pixinguinha, one of the legends of Brazilian musicians, clearly played an important role in shaping the modern form of Samba in early $20^{\text {th }}$ century. One particular style that emerged around that time was choro, a mixture of Afro-Brazilian style with European characteristic. It actually had some similarities with New Orleans jazz style pioneered by Louis Armstrong, King Oliver, and Jelly Roll Morton (Moreno, 1982, p.131). This remarked Brazil's first encounter with the American jazz. What happened at that time was simply an imitation of jazz style by the Brazilian musicians, and they spread the style throughout the country. It was still not as fundamental as Bossa Nova's invention later in the 1950s. Regardless, that was a very significant event that would help the country to develop their cultural, especially musical potent. After that, Brazilian music was about to take another important step as Getulio Vargas saw himself appointed to the presidency in 1930 with the help of the military. He was a dictator, but at the same time he was a populist who was famous among his own people.

Vargas revolutionary action based within his ideology of synthesizing a symbol of national identity. Ruling over a country with such enormous territory and population, Vargas knew that Brazil needed a symbol of identity, a national representation that also played the role as a unifier of two racial groups, blacks and whites Brazilian. He was so fortunate that the symbol that he needed had already been there from the beginning of the country's history. With a society which gave so much emphasis in their music and culture, nothing was more suitable to be the nation's symbol other than the samba itself and Vargas did nothing wrong to make the decision of giving samba the title as national music. In order to support his new ideas, Vargas started by letting the escolas de samba (samba schools) to take part in carnival celebrated in the capital city Rio de Janeiro. 
Escolas de samba was a kind of organization consisting of sambistas (samba artists) and performers in which they met and made plans for performances and festivals (Moreno, 1982, p.131).

Therefore, one could say that samba represents Brazil, a nation that is built upon a foundation of two dominant racial groups. It is the embodiment of the white Europeans and black Africans cultures, which are merged into one big society and, in a wider context, a nation. All are summed up in one word, the brasiliadade (Brazilian-ness). In this brasiliadade, there is no dominant or minor ethnical group. Discussing brasiliadade means you discuss both the white and black cultures. America, for example, is a country consists of various racial groups, but each culture defines its own. It should not be considered as the representation of America as a whole. Hip-hop music might be more popular to the black Americans, while country music is much more preferred by some white Americans, for instance. Of course, the trend has changed as more people from other ethnical groups begin to enjoy other groups' cultural production, but in Brazil, samba is the music for the Brazilians, without taking into account their ethnical origins (Behague, 1973, p.209).

\section{Transnational Relationship and Brazilian Urban Middle Class}

Samba enjoyed its privileged status as national music only as long as President Vargas' administration, which ended in 1954 following his death. The new president, Juscelino Kubitschek, had a rather different idea for the future of Brazil. He believed that the only way to move the country forward was by stimulating developments and modernization in every aspect, such as economy, politic, and culture, rather than championing the effort of promoting national symbol. His most famous program was 'fifty years of development in only five'. In order to achieve that, Kubitschek saw no other way than for Brazil to import and adapt foreign resources and styles for the wealth and modernization of the nation. Therefore, transnational relationship between Brazil and western countries, especially America, was inevitable (Sovik, 1994). The jazz influence that Pixinguinha and other choro performers brought many years ago would see a brand new era where jazz would bloom in every local club and dancing hall.

This era of modernism and developmentalism had brought new ideas and concepts among the Brazilians, especially those from the urban middle class. One major ideology that emerged from those people was none other about the existence of samba. Samba, which once had been the national music of Brazil, was seen as something outdated. It was a product of the old regime and, because of its association with the black poorer class, was considered as a low musical form of the lower class (Moreno, 1982, p.133). There was nothing wrong in the first place with the concept of a 'unifying national music', but samba needed to change and revolutionize itself to become more than just a symbol of national music in order to keep up with the rapid development in 
Brazil. By simply keeping its status as a mere symbol, samba was deemed as stagnant by people, especially from the urban middle class (ibid, p.135). This urban middle class was those educated people who preferred jazz and classic as their musical interests.

The urban middle class' rejection of samba was also triggered by the social changes since the era of President Kubitschek. In addition to the modernism and developmentalism, Kubitschek's administration also caused rural-influenced foundations to start losing its position replaced by the urban-influenced industrial might which ran the development of the new Brazil (Reily, 1996, p.5). This led to more gaps between the higher and the lower class, and to think that the poorer class was actually the backbone of samba with their samba schools' participation in the Rio's festival, it was no surprise that samba received the same fate of being left out from the nation's large-scale plan. Besides that, this ambitious project created an environment where the young generation from the urban middle class grew up in a very prosperous era where modernity and prosperity were just behind the corner, and this atmosphere was not in any way forced into the society by the Kubitschek's administration, but rather it was a natural phenomenon that followed the era (Behague, 1973, p.211). Therefore, the exclusion and excommunication of samba were inevitable at that moment; it was just like a natural disaster that no one could do anything about it.

However, despite the fact that modernism and developmentalism were naturally everywhere in Brazil, the conflict between traditional heritages and foreign influences was still appropriate to be addressed. It was preordained that foreign influences would invade Brazil since President Kubitschek agreed to open a new transnational relationship with America. The influences were inarguably important in helping the development of Brazil, as well as the President's ambition to wrap up fifty years of development into five. However, there were still those who doubted the positive impact of foreign influences to Brazil's cultural life. Jorge Amado, a renowned and well-established novelist, published his work in 1958 titled Gabriela, which discussed the conflict of traditionalism and modernism (Moreno, 1982, p.134). The urban middle class was undoubtedly familiar to modernism and everything which represented elegance and sophistication, but at the same time they wanted something which also epitomized the contemporariness of Brazilian heritage. Jazz was pretty much a very agreeable style that represented this middle class ideology. However, jazz was a foreign product, an import of the President's ambitious plan, and obviously jazz was not the ultimate form which the urban middle class was looking for.

\section{The Quintessence of Reinvigorated and Contemporary Samba through Bossa Nova}

The style which the urban middle class sought was not apparent until Dorival Caymmi's first attempt in the mid-1950s to introduce the modern chords with four or more notes and to some extent the use of chromaticism, all of which were the elements 
of American jazz (Moreno, 1982, p.132). The jazz influences that he offered were improvements over the raw jazz style which was directly imported from the America, since Caymmi tried to blend it with the local style. Although nothing significant was happening at that moment, it could be considered as the first step toward the invention of the style which characterized a contemporary Brazilian style. The first song which marked the era of Bossa Nova was Antonio Carlos “Tom" Jobim's Chega de Saudade. The song's melody was accented with the landmarks of Bossa Nova, such as the constant modulations and surprising intervals (Reily, 1996, p. 4). Those elements could also be found in many jazz compositions, and it was not astounding since Tom was heavily influenced by classic and jazz.

However, the most important thing from that was the song had brought together three major figures in the history of Bossa Nova's invention. Tom's smart composition was accompanied by captivating lyrics from the well-recognized poet, Vinicius de Moraes. Vinicius was among the generations of artists who based their works on the modernism (Moreno, 1982, p. 135), and his lyrics perfectly fit the developmentalistic and modernistic environment of the ever growing ambitious Brazil under the administrations of Kubitschek. Furthermore, his idea was also in line with the ideology of the urban middle class, who sought a contemporary Brazilian musical style, since his lyrics deeply involved with Brazilian everyday life, also a typical of many classic samba songs. His lyrics in the song A Felicadade (Happiness), also composed by Tom, dealt with the misery of the poor lower class. Some lines from the song said,

Tristeza nao tem fim (Sadness never ends)

Felicidade sim (Happines does)

...

A felicidade do pobre parece, (The happiness of the poor)

A grande illusao do carnaval (Is a grand illusion of carnival)

In this song he explicitly highlighted the situation of the Brazilian poorer class. To be more specific, he mentioned the carnival, where many samba schools performed and played samba. With this Vinicius clearly referred to the life of the black poorer class.

If Tom created the compositions with the company of Vinicius' poetic lyrics, then it was Joao Gilberto who founded the distinguished style of classic Bossa Nova. His notable guitar style was heavily influenced by traditional samba and choro traditions (Reily, 1997, p.12). He manipulated his thumb and fingers to personify the beat of pandeiro and tambourim, two native percussions from Brazil that are widely used in traditional samba. ${ }^{5}$ His method made it possible for the original samba rhythm to be redefined into

\footnotetext{
5 This unique guitar style of his has influenced and been imitated by many newer generation of musicians, such as Jacques Morelenbaum, Caetano Veloso, and Gilberto Gil. The style and Brazilian music in general also get special attentions in Japanese music scene. The Brazilian-born Japanese singer and songwriter
} 
a more sophisticated and defined musical style. Furthermore, 'more defined' also meant that samba would be interpreted in a much simpler way, yet keeping the complexity of modern musical style such as jazz. For one thing, Bossa Nova songs were commonly played with a maximum of four-man band, contrasted to the traditional samba carnaval which involved big samba schools with so many percussions, instruments, performers and dancers.

In addition to its instruments and number of performers, the simplicity of this new Brazilian beat was also evident in many of the genre's compositions. For example, Jobim's Samba de Uma Nota So (One Note Samba) tried to explore the genre's uncomplicatedness through the musicality of one's compositions. As the title suggested, Jobim composed this song by utilizing only one note for the song's melody. The result of his effort, however, was not something tasteless or plain. Actually, the song turned out to be a quite intricate one, giving more room for singers and performers to incorporate their improvisations and harmonizations. Again, this is one main distinctive feature of jazz, in which improvisations are generously encompassed. The theme of the songs could also represent the simplicity and innocence of Bossa Nova. Garota de Ipanema (The Girl from Ipanema) talked about the admiration of a shy and simple man to a beautiful girl, who walked from the street to the beach in Ipanema. Desafinado (Off-Key) told the effort of a toned deaf man to impress his lover by singing a song. It was all so simple, no explicit political message or persuasion for revolting, yet this was the main feature that showed the complexity of Bossa Nova, how it could simplify the once grand and big samba rhythm, in terms of instruments, musicality, and themes.

Then, it was just like Carney said in his paper about the invention of jazz in America, in which the early jazz from New Orleans “... signified ... a conjunction of rural and urban culture ... and the violent past and an encouraging future" (2003, p.40). Especially for the immigrants of early 1920s in New Orleans, black and white immigrants, jazz was the instrument of adapting young migrants to urban life (ibid). On more general term, jazz was seen as music capable of conveying modernity and advancement. That is why, even until now, jazz is considered as something only for classy people and not your average music, although it is, in fact, a form of popular cultures. This spirit of modernity was what the Brazilian musicians in early 1960s saw from jazz. They believed by integrating jazz into local context, they could reinvigorate Brazil's music scene. Just like New Orleans jazz helped the adaptation of new immigrants the urban life, Bossa Nova helped the Brazilians and samba to acclimatize to the new environment of progressivism and developmentalism of President Kubitschek's era.

Lisa Ono and the acid jazz duo Orange Pekoe have been noted to have a similar style with Joao's. 


\section{CONCLUSION}

This paper was set out to find the relationship between Bossa Nova and the traditional form of samba. It was intended to discover the role of Bossa Nova in reinvigorating and redefining the original form of samba, which was seen as dead by many Brazilians in the mid-1950s. I reviewed the Brazilians urban middle class' efforts, which had been made to revive samba by searching for a new form of sophisticated samba, or jazzy samba. To accomplish those objectives, I had examined the chronological history of the original samba, from its early invention, the modifications and evolutions of urban samba, its accomplishment in achieving the status of national under the administration of President Vargas, to its stagnation in President Kubitschek' era. Observations had also been made regarding the inventions of Bossa Nova, its intrinsic and extrinsic elements, and also the ever important jazz influence in it.

It is true that Bossa Nova was influenced by American jazz as a result of President Kubitschek's decision to open a transnational relationship with America which saw jazz entered the Brazilian music scene in the 1950s. However, Bossa Nova was not a plain mixture between samba and jazz. Bossa Nova merely borrowed some of jazz's features in order to give new fresh feeling to the old samba. Then it was all about samba and its rhythm in Bossa Nova, not jazz and its foreign characteristics. Through Bossa Nova, the Brazilians could listen to their national music, samba with all its distinctive features of brasiliadade without being bored by the stagnant samba and altogether without the need to worry if the music was a foreign product. Bossa Nova is not jazz, it is samba and this fact will not change even if the jazz influence was already there from the very beginning of its invention.

However, the era and musical movements after Bossa Nova are not something to be put aside. The military regime that came just after President Kubitschek's administration forced Bossa Nova to evolve. An era of censorship and banning left no room for Bossa Nova. Protests and revolts were needed, and new musical genre appeared from that situation. Advanced review on Tropicalismo may be needed to further study the reinvigoration of samba, as it continued the legacy of Bossa Nova which ended prematurely in the 1964-65.

\section{BIBLIOGRAPHY}

Behague, G. (1973). Bossa \& bossas: recent changes in brazilian urban popular music. Ethnomusicology, 17 (2), 209-233. Retrieved December 28, 2011 from http://www.jstor.org/ stable/849882

Carney, C. P. (2003). Jazz and the cultural transformation of America in the 1920s. (Doctoral dissertation, Louisiana State University, 2003). Retrieved November 18, 2012 from http:// etd.lsu.edu/docs/available/etd-1110103-161818/unrestricted/Carney_dis.pdf 
Magaldi, C. (1999). Adopting imports: new images and alliances in brazilian popular music. Popular Music, 18 (3), 309-329. Retrieved March 30, 2012 from http://www.jstor. org/ stable/853610

McCann, B. (2007). Blues and samba: another side of bossa nova history. Luso-Brazilian Review, 44 (2), 21-49. Retrieved March 29, 2012 from http://www.jstor.org/stable/30219526

Moreno, A. (1982). The significance of bossa nova as brazilian popular music. Latin American Research Review, 17 (2), 129-141. Retrieved December 28, 2011 http://www.jstor. org/stable/2503147

Reily, S. A. (1996). Tom Jobim and the bossa nova era. Popular Music, 15 (1), 1-16. Retrieved December 28, 2011 from http://www.jstor.org/stable/931201

Samba: origins of samba. (n.d). Retrieved Octeber 5, 2011 from http://www.rawsamba. org.uk/samba.htm

Starr, E. (2007). Batucada, samba, and bossa nova - history and development drummers guide. Retrieved October 5, 2011 from http://www.article-searchengine.com/Art/1529/6/ Batucada-Samba-And-Bossa-Nova-History-And-Development-Drummers-Guide.html

Thompson, D. (1998). Plain Joao, the man who invented bossa nova. Retrieved October 5, 2011 from http://daniellathompson.com/Texts/Brazzil/Plain_Joao.htm 